\title{
First Serological Evidence of Borna Disease Virus in Healthy Horses from Yucatan, Mexico
}

\author{
Marco Torres-Castro1, Henry Noh-Pech1, Edwin Gutiérrez-Ruiz², Julián García-Rejón1, \\ Carlos Machain-Williams ${ }^{1}$, Jorge Zavala-Castro', Fernando I. Puerto1 ${ }^{1 *}$ \\ ${ }^{1}$ Centro de Investigaciones Regionales “Dr. Hideyo Noguchi”, Universidad Autónoma de Yucatán, Mérida, \\ México \\ ${ }^{2}$ Campus de Ciencias Biológicas y Agropecuarias, Universidad Autónoma de Yucatán, Mérida, México \\ Email: "pmanzano@correo.uady.mx
}

Received 26 January 2016; accepted 14 June 2016; published 17 June 2016

Copyright (C) 2016 by authors and Scientific Research Publishing Inc.

This work is licensed under the Creative Commons Attribution International License (CC BY).

http://creativecommons.org/licenses/by/4.0/

c) (i) Open Access

\begin{abstract}
Borna Disease Virus (BDV) causes a progressive non-suppurative meningoencephalitis that sometimes occurs in mortality; this disease has been reported for over two centuries ago in horses, sheep and cats in Central Europe and some regions of Asia. Currently, it is known that it causes neurological symptoms in various species of vertebrates including human beings. In Yucatan, Mexico, there is a single serological report about the circulation of BDV in schizophrenia patients; however, nothing is known about the circulation in animals. We obtained serum samples of 100 horses without apparent clinical signs caused by BDV infection, from various sites in the region. Antibodies against BDV were detected by electrochemiluminescence immunoassay (ECLIA) method with three recombinant proteins: BDV p24, BDV p40 and BDV p10 as antigens; obtaining a high seroprevalence of $44 \%(44 / 100)$. This study generates the first report of the probable activity of the BDV in healthy horses in Mexico and has expanded the infiltration area of BDV in the world. Nevertheless, several molecular investigations are required to detect BDV-RNA circulating and find sequences for clarification of the origin of BDV in Mexican horses.
\end{abstract}

\section{Keywords}

Borna Disease Virus, Electrochemiluminescence Immunoassay, Healthy Horses, Yucatan, Mexico

\section{Introduction}

Borna Disease Virus (BDV) is an enveloped virus with a negative-strand RNA, non-segmented, non cytolytic

*Corresponding author.

How to cite this paper: Torres-Castro, M., Noh-Pech, H., Gutiérrez-Ruiz, E., García-Rejón, J., Machain-Williams, C., ZavalaCastro, J. and Puerto, F.I. (2016) First Serological Evidence of Borna Disease Virus in Healthy Horses from Yucatan, Mexico. Advances in Microbiology, 6, 489-494. http://dx.doi.org/10.4236/aim.2016.67048 
and neurotrophic, with a genome of approximately $8.9 \mathrm{~Kb}$. It is the only member of the family Bornaviridae within the order Mononegavirales [1]. The BDV genome contains six major open reading frames (ORFs). Four strains of BDV have been described: Borna V, Borna HE/80, Borna No/98 and Borna H1766. Strain H1766 has 95\% - 98\% homology with strains $\mathrm{V}$ and $\mathrm{He} / 80$, and only $81 \%$ with Borna No/98. Other minor variants have been reported as avian Bornavirus [2]. BDV infection causes disease in the central nervous system (CNS) of many vertebrate species, which is frequently manifested by behavioural abnormalities and even fatalities [3].

Recognized since 18th century ends, BDV natural infection was present in horses and sheep in central Europe and Asia. Currently, natural infection has been characterized in a broad range of hosts worldwide, suggesting that the range of hosts, as well as its geographic distribution and rates of prevalence, have been underestimated [3]. Furthermore, mounting evidence indicates that BDV infection occurs in human beings and that it may be related to neuropsychiatric diseases [4].

BDV infection in horses causes a fatal immune-mediated neurological disorder, characterized by a severe, progressive non-suppurative meningoencephalomyelitis with massive perivascular and parenchymal infiltration, with a predilection for the grey matter of brain, brainstem and hippocampus. The present clinical signs (ataxia, somnolence, depression, and gait abnormalities) are mainly related to CNS abnormalities [4] [5]. The incubation period of Borna disease ranges widely, from two weeks to several months [6]. Most cases of Equine Borna Disease (EBD) have been reported from Central Europe. However, BDV infection markers in horses have been reported worldwide [3]. This study illustrates the first evidence of antibodies against BDV infection in clinical healthy horses, and also generates the first report of the probable activity of BDV in animals from Mexico.

\section{Materials and Methods}

\subsection{Sampling}

From July to October, 2002, blood samples $(5 \mathrm{ml})$ were taken from the jugular vein from domestic horses (Equus caballus) in four study sites (Figure 1), using Vacutainers tubes (Dickinson and Co, USA) with ethylenediaminetetraacetic acid (EDTA) as anticoagulant. The blood samples were immediately centrifuged and sera were preserved at $-80^{\circ} \mathrm{C}$ until use in the serological analysis.

Horse owners in selected study sites, were asked to participate in the study and consent was gained to bleed the horses. Owners reported that the horses never have left Mexico or come from abroad.

The climate of the study sites is tropical with an average annual temperature of $26^{\circ} \mathrm{C}$. The average annual rainfall in each study site ranges from 600 to $1100 \mathrm{~mm}$.

Clinical and neurological examinations of the sampled horses were performed by an expert veterinarian team.

\subsection{Electrochemiluminescence Immunoassay System}

Anti-BDV antibodies were detected in the serum samples by a electrochemiluminescence immunoassay system (ECLIA), using as antigens two recombinant proteins described by Yamaguchi et al. [7] [8]: BDVp24 and BDV p40. P40 corresponds to the viral nucleoprotein $(\mathrm{N})$ and p24 to the phosphoprotein $(\mathrm{P})$. Also, we used a peptide BDV p10 protein. The ECLIA system is a highly sensitive and specific serological screening tool for the measurement of anti-BDV antibodies to BDV p24 and BDV p40 in human beings and animal serum samples [9].

Following the methodology of Yamaguchi et al. [7] [8], a sample was considered temporarily positive in the first screening, if the mean ECLIA account was higher than the cutoff accounts $(1,000)$ against mixed proteins (p10, p24 and p40). This is based on the mean plus two standard deviations of ECLIA accounts of samples horses which had been confirmed as seronegative for BDV by indirect immunofluorescence assay (IFA). The ECLIA account was computed by an automatic ECLIA analyzer (Sanko Junyaku Co ${ }^{\circledR}$, Tokyo, Japan) based on optical density at $620 \mathrm{~nm}$.

The temporarily positive sera, were reexamined with the following inhibition test to confirm the specificity. Each sample was incubated for 15 minutes at $37^{\circ} \mathrm{C}$, with PBS containing $10 \%$ rabbit serum and recombinant proteins. Serum samples incubated with PBS containing $10 \%$ serum alone, served as a control. A serum sample was declared anti-BDV antibody positive if the ECLIA account was inhibited to more than $50 \%$ of the control accounts [7] [8]. These positives samples were further examined again by ECLIA respectively for p10, p24 and $\mathrm{p} 40$. 


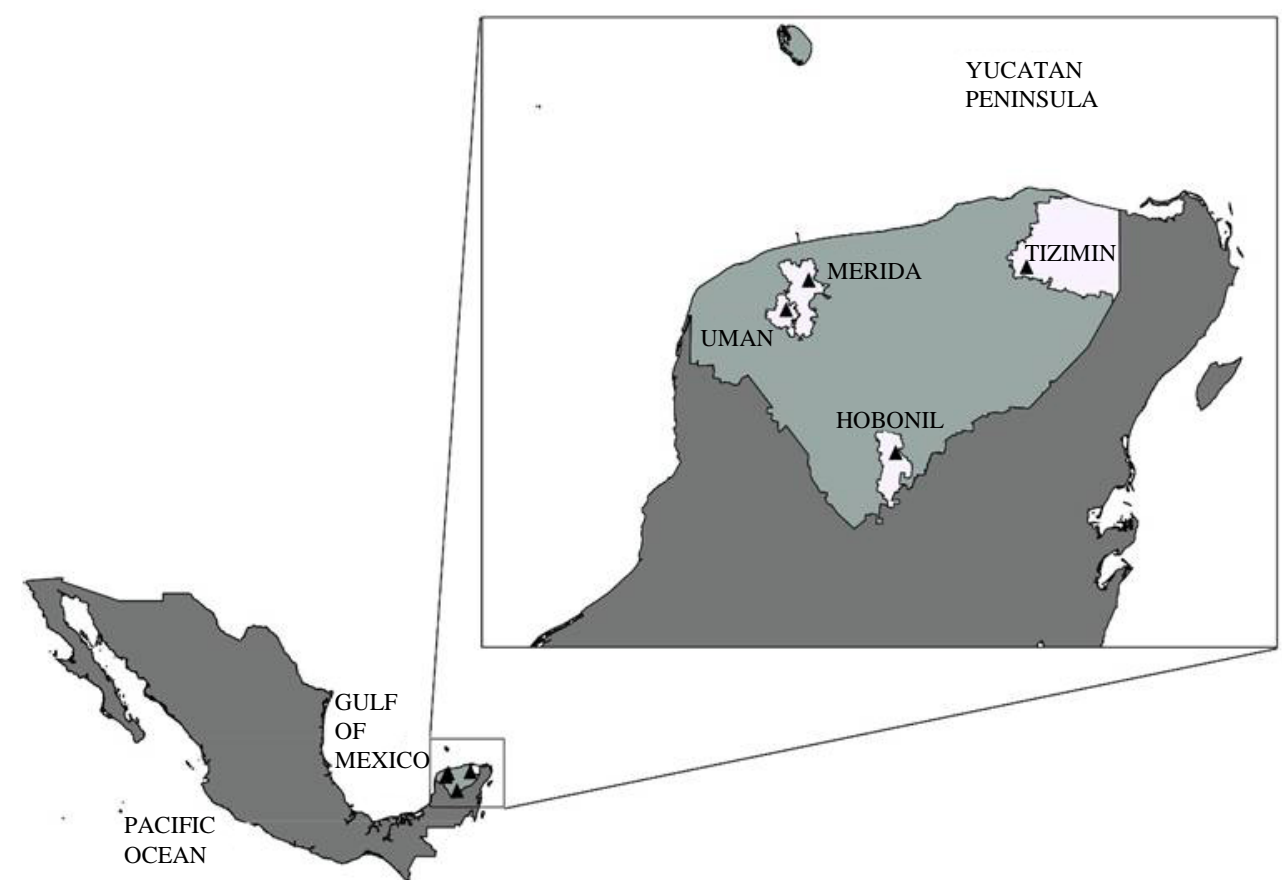

Figure 1. Map of Mexico showing the localization of Yucatan State (inset) and the study sites (black triangles).

\section{Results}

A total of 100 local horses without apparent clinical signs caused by BDV infection were sampled (Table 1). The age distribution of the horses was from 1 to 28 years; the mean age was 9.3 years. 37\% (37/100) of horses were female and $63 \%$ (63/100) were male. The horses were separated according their zootechnical purpose as shown in Table 2. The feral horses did not have any vaccine, the other horses received vaccines against Rabies Virus and tetanus. Also, 49 horses had Venezuelan Encephalitis Equine Virus (VEEV) vaccine.

As shown in Table 2, 44\% (44/100) of the horses were judged as seropositive for anti-BDV antibodies by the ECLIA method. The higher seropositive percentage (11\%) was for jumping and ranch horses, and the lowest percentage (4\%) was for "charro" horses. 10\% (10/100) of the horses were counted as BDV seropositive against the p40 recombinant protein and only $1 \%(1 / 100)$ was positive for p24 + p40 recombinant proteins. At least one horse of each zootechnical purpose and age was seropositive. All recombinant proteins used had reacted with at least one serum sample.

\section{Discussion}

This study reports the first serological evidence of BDV circulation in healthy horses from Mexico. Although Mexico never was considered an endemic country for EBD, our seroprevalence percentage reported (44\%) is as high as that found in endemic regions. Likewise, ours results reveals and supports that BDV circulation is commonly found in horses and other species in the absence of observable clinical signs [3] [10]. We suspect that one possible route of transmission of BDV is by migratory birds, because wild birds have been indicated as potential reservoirs [3] [11]; the Yucatan Peninsula is a point where converge multiples species of migratory birds that can be in contact with livestock and eventually with horses [12]. Additionally, we know that currently, there are no specific restrictions, tests or reporting requirements for horses being imported into Mexico from EBD endemic areas. Thus, within the context of increasing movements of horses internationally, veterinarians should be aware of Borna disease and consider it as a differential diagnosis for any horse, with a history of travel to or from an endemic area, and that presents with central nervous signs [13].

The prevalence of BDV-seropositive by ECLIA in the whole horse material used in this study, was $44 \%$ (44/ 100) (Table 2). These positive antibody reactions were observed in asymptomatic horses; this fact is equal to that reported by several investigators in different countries as Japan [9] [14], Sweden [15], Bangladesh [16], 
Table 1. Study sites, global positioning system (GPS) location and number of horses sampled by each one.

\begin{tabular}{|c|c|c|c|}
\hline & Study site & Global Positioning System Location & No. of horses (\%) \\
\hline & Hobonil & $20^{\circ} 00^{\prime} 54^{\prime \prime} \mathrm{N}, 89^{\circ} 01^{\prime} 15^{\prime \prime} \mathrm{W}$ & $22(22 \%)$ \\
\hline & Mérida & $20^{\circ} 58^{\prime} 04^{\prime \prime N}, 89^{\circ} 37^{\prime} 18^{\prime \prime W}$ & 39 (39\%) \\
\hline & Tizimín & $21^{\circ} 08^{\prime} 32^{\prime \prime N}, 88^{\circ} 09^{\prime} 03^{\prime \prime} \mathrm{W}$ & $24(24 \%)$ \\
\hline & Umán & $20^{\circ} 49^{\prime} 38^{\prime \prime N}, 89^{\circ} 41^{\prime} 08^{\prime \prime} \mathrm{W}$ & $15(15 \%)$ \\
\hline Total & & & $100(100 \%)$ \\
\hline
\end{tabular}

Table 2. Number and percentage of healthy horses from Yucatan, Mexico, positives to anti-BDV antibody.

\begin{tabular}{ccccccccc}
\hline $\begin{array}{c}\text { Zootechnical } \\
\text { purpose }\end{array}$ & $\mathrm{p} 10+\mathrm{p} 24+\mathrm{p} 40(\%)$ & $\mathrm{p} 10+\mathrm{p} 24(\%)$ & $\mathrm{p} 10+\mathrm{p} 40(\%)$ & $\mathrm{p} 24+\mathrm{p} 40(\%)$ & $\mathrm{p} 40(\%)$ & $\mathrm{p} 10(\%)$ & $\mathrm{p} 24(\%)$ & Total (\%) \\
\hline Jumping & $3(3 \%)$ & $2(2 \%)$ & $1(1 \%)$ & $1(1 \%)$ & $1(1 \%)$ & $2(2 \%)$ & $1(1 \%)$ & $11(11 \%)$ \\
Riding & $3(3 \%)$ & & & & $2(2 \%)$ & $4(4 \%)$ & $1(1 \%)$ & $10(10 \%)$ \\
Horse ranch & $3(3 \%)$ & $1(1 \%)$ & $1(1 \%)$ & & $2(2 \%)$ & $1(1 \%)$ & $3(3 \%)$ & $11(11 \%)$ \\
Feral & & $1(1 \%)$ & $1 \%(1 \%)$ & & $5(5 \%)$ & $1(1 \%)$ & $8(8 \%)$ \\
& & $2(2 \%)$ & & & & & $2(2 \%)$ & $4(4 \%)$ \\
Total & & $6(6 \%)$ & $3(3 \%)$ & $1(1 \%)$ & $10(10 \%)$ & $7(7 \%)$ & $8(8 \%)$ & $44(44 \%)$ \\
\hline
\end{tabular}

Turkey [17], Finland [18] and Italy [19]. Additionality, in Japan [20] and France [21], were reported RNA-positive BDV infection also in healthy horses. Our report expanded the infiltration area of BDV circulation in the world.

In comparison with previous serological studies made in asymptomatic horses, the seroprevalence of our research was superior to several reports made in endemic countries such as Japan [14] [22], Sweden [15], Bangladesh [16], France [23], China [10] [24], Turkey [17] [25], Australia [26], Italy [19] and Finland [18]. A serological report made in Japan [9], shows similitude with the percent of seroprevalence of our research. By the other hand, Berg et al. [15] and Björnsdóttir et al. [13], reported a superior seroprevalence than ours but in symptomatic horses. In Central America, there is a unique molecular report, made by Barrantes-Rodríguez et al. [27], of the circulation of BDV in Costa Rican healthy horses.

How BDV is transmitted among horses, remains unclear. BDV-specific RNA has been detected in the saliva, nasal secretions and conjunctival fluid of horses with neurological clinical signs, so BDV may be is transmitted through physiological contact with these secretions of infected horses [28]. This supports the hypothesis made by Inoue et al. [9], that transmission of BDV can be more common in horses with close contact compared with horses in feral practice. Most of the seropositive horses in this study were ranch horses and jumping horses, where bovine, equine and swine farms are very common; this fact suggests that infection is endemic and that BDV was probably transmitted from horse to horse [27].

In Yucatan, the only evidence of the circulation of BDV was in schizophrenic patients [29], so nothing was known about the circulation in animals, this probably to the lack of differential diagnosis in horses or others domestic animals with nervous symptomatology. Although serological prevalence is high, it is recommended make several molecular studies to determine accurately the circulation of BDV [26]. Further investigation is required to detect BDV-RNA and to find some characteristic sequences for clarification of the origin of BDV in Mexican horses. Likewise, it is necessary to expand the species (domestic and wild) that is now known, are involved in the infection cycle, and make a new sampling in horses, since, over the years, the seropositive percentage can be different.

\section{Conclusion}

This study presents the first evidence of antibodies against to BDV in horses without neurological signs from Mexico. The questions of how Bornavirus has entered the country and to what extent markers of Bornavirus infection can be found in humans and animals in Mexico, remain to be answered; for this, further molecular investigation is required, also for characterization of the etiological agents of nervous disorders in horses from Mexico. 


\section{Acknowledgements}

We thank to the Secretaría de Investigación, Innovación y Educación Superior of the Government of Yucatan, by the funding for the publication of this work, especially to Dr. Raúl Humberto Godoy-Montañéz, Secretary.

\section{References}

[1] Cubitt, B., Oldstone, C. and de la Torre, J.C. (1994) Sequence and Genome Organization of Borna Disease Virus. Journal of Virology, 68, 1382-1396.

[2] Kolodziejek, J., Durwald, R., Herzog, S., Ehrensperger, F., Lussy, H. and Nowotny, N. (2005) Genetic Clustering of Borna Disease Virus Natural Animal Isolates, Laboratory and Vaccine Strains Strongly Reflects Their Regional Geographical Origin. Journal General of Virology, 86, 385-398. http://dx.doi.org/10.1099/vir.0.80587-0

[3] Kinnunen, P.M., Palva, A., Vaheri, A. and Vapalahti, O. (2013) Epidemiology and Host Spectrum of Borna Disease Virus Infections. Journal of General Virology, 94, 247-262. http://dx.doi.org/10.1099/vir.0.046961-0

[4] Solbrig, M.V. (2010) Animals Models of CNS Viral Disease: Examples from Borna Disease Virus Models. Interdisciplinary Perspectives on Infectious Diseases, 2010, 709-791. http://dx.doi.org/10.1155/2010/709791

[5] Lipkin, W.I., Briese, T. and Hornig, M. (2011). Borna Disease Virus_Fact and Fantasy. Virus Research, 162, $162-172$. http://dx.doi.org/10.1016/j.virusres.2011.09.036

[6] Katz, J.B., Alstad, D., Jenny, A.L., Carbone, K.M., Rubin, S.A. and Waltrip II, R.W. (1998) Clinical, Serologic, and Histopathologic Characterization of Experimental Borna Disease in Ponies. Journal of Veterinary Diagnostic Investigation, 10, 338-343. http://dx.doi.org/10.1177/104063879801000405

[7] Yamaguchi, K., Sawada, T., Naraki, T., Igata-Yi, R., Shiraki, H., Horii, Y, et al. (1999) Detection of Borna Disease Virus-Reactive Antibodies from Patients with Psychiatric Disorders and from Horses by Electrochemiluminescence Immunoassay. Clinical and Diagnostic Laboratory Immunology, 6, 696-700.

[8] Yamaguchi, K., Sawada, T., Yamane, S., Haga, S., Ikeda, K., Igata-Yi, R., et al. (2001) Synthetic Peptide-Based Electrochemiluminescence Immunoassay for Anti-Borna Disease Virus p40 and p24 Antibodies in Rat and Horse Serum. Annals of Clinical Biochemistry, 38, 348-355. http://dx.doi.org/10.1258/0004563011900867

[9] Inoue, Y., Yamaguchi, K., Sawada, T., Rivero, J.C. and Horii, Y. (2002) Higher Prevalence of Anti-Borna Disease Virus Antibodies in Stabled than in Feral Horses in Japan. Equine Veterinary Journal, 34, 741-743. http://dx.doi.org/10.2746/042516402776250397

[10] Zhang, L., Wang, X., Zhan, Q., Wang, Z., Xu, M., Zhu, D., et al. (2014) Evidence for Natural Borna Disease Virus Infection in Healthy Domestic Animals in Three Areas of Western China. Archives of Virology, 159, 1941-1949. http://dx.doi.org/10.1007/s00705-013-1971-5

[11] Payne, S.L., Delnatte, P., Guo, J., Heatley, J.J., Tizard, I. and Smith, D.A. (2012) Birds and Bornaviruses. Animal Health Research Reviews, 13, 145-156. http://dx.doi.org/10.1017/S1466252312000205

[12] Cortés-Ramírez, G., Gordillo-Martínez, A. and Navarro-Sigüenza, A.G. (2012) Patrones biogeográficos de las aves de la Península de Yucatán. Revista Mexicana de Biodiversidad, 83, 530-542.

[13] Björnsdóttir, S., Agustsdóttir, E., Blomström, A., Örde, Ö.I., Treiberg, B.L., Svansson, V., et al. (2013) Serological Markers of Bornavirus Infection Found in Horses in Iceland. Acta Veterinaria Scandinavica, 55, 77-80. http://dx.doi.org/10.1186/1751-0147-55-77

[14] Takahashi, H., Nakaya, T., Nakamura, Y., Asahi, S., Onishi, Y., Ikebuchi, K., et al. (1997) Higher Prevalence of Borna Disease Virus Infection in Blood Donors Living near Thoroughbred Horse Farms. Journal of Medical Virology, 52, 330-350. http://dx.doi.org/10.1002/(SICI)1096-9071(199707)52:3<330::AID-JMV16>3.0.CO;2-M

[15] Berg, A.L., Dorries, R. and Berg, M. (1999) Borna Disease Virus Infection in Racing Horses with Behavioral and Movement Disorders. Archives of Virology, 144, 547-559. http://dx.doi.org/10.1007/s007050050524

[16] Khan, M.A., Yamaguchi, K., Miyata, H., Kazi, A., Kamahora, T. and Hino, S. (2000) Prevalence of Anti-Borna Disease Virus Antibody in Horses and Their Caretakers in Bangladesh. Yonago Acta Medica, 43, 59-67.

[17] Yilmaz, H., Helps, C.R., Turan, N., Uysal, A. and Harbour, D.A. (2002) Detection of Antibodies to Borna Disease Virus (BDV) in Turkish Horse Sera Using Recombinant p40. Archives of Virology, 147, 429-435. http://dx.doi.org/10.1007/s705-002-8331-8

[18] Kinnunen, P.M., Palva, A., Vaheri, A. and Vapalahti, O. (2013) Epidemiology and Host Spectrum of Borna Disease Virus Infections. Journal of General Virology, 94, 247-262. http://dx.doi.org/10.1099/vir.0.046961-0

[19] Pisoni, G., Nativi, D., Bronzo, V. and Codazza, D. (2007) Sero-Epidemiological Study of Borna Disease Virus Infection in the Italian Equine Population. Veterinary Research Communications, 31, 245-248. http://dx.doi.org/10.1007/s11259-007-0016-5 
[20] Nakamura, Y., Kishi, M., Nakaya, T., Asahi, S., Tanaka, H., Sentsui, H., et al. (1995) Demostration of Borna Disease Virus RNA in Peripheral Blood Mononuclear Cells from Healthy Horses in Japan. Vaccine, 13, 1076-1079. http://dx.doi.org/10.1016/0264-410X(95)00050-B

[21] Dauphin, G., Legay, V., Sailleau, C., Smondack, S., Hammoumi, S. and Zientara, S. (2001) Evidence of Borna Disease Virus Genome Detection in French Domestic Animals and in Foxes (Vulpes vulpes). Journal of General Virology, 82, 2199-2204. http://dx.doi.org/10.1099/0022-1317-82-9-2199

[22] Hagiwara, K., Okamoto, M., Kamitani, W., Takamura, S., Taniyama, H., Tsunoda, N., et al. (2002) Nosological Study of Borna Disease Virus Infection in Race Horses. Veterinary Microbiology, 4, 367-374. http://dx.doi.org/10.1016/S0378-1135(01)00446-1

[23] Galabru, J., Saron, M.F., Berg, M., Berg, A.L., Herzog, S., Labie, J., et al. (2000) Borna Disease Virus Antibodies in French Horses. The Veterinary Record, 147, 721-722.

[24] Hagiwara, K., Asakawa, M., Liao, L., Jiang, W., Yan, S., Chai, J., et al. (2001) Seroprevalence of Borna Disease Virus in Domestic Animals in Xinjiang, China. Veterinary Microbiology, 80, 389-389. http://dx.doi.org/10.1016/S0378-1135(01)00324-8

[25] Yeşilbağ, K., Herzog, S., Kennerman, E., Tuncer, P., Schmid, S., Kaya, G., et al. (2012) Serological Evidence for Infections with Borna Disease Virus in Turkey. Berliner und Münchenertierärztliche Wochenschrift, 125, 452-455.

[26] Kamhieh, S., Hodgson, J., Bode, L., Ludwig, H., Ward, C. and Flower, R.L. (2006) No Evidence of Endemic Borna Disease Virus Infection in Australian Horses in Contrast with Endemic Infection in Other Continents. Archives of Virology, 151, 709-719. http://dx.doi.org/10.1007/s00705-005-0655-1

[27] Barrantes-Rodríguez, X., Silva, S., Macaya, G. and Bonilla, J.A. (2013) Detection of Borna Virus Disease by RealTime RT-PCR in Costa Rican Equines and Humans. Archives of Clinical Microbiology, 3, No.1.

[28] Okayama, S., Miura, N., Murakami, M., Funaba, M. and Nishino, Y. (2009) Changes in Borna Disease Virus Genome with Adaptation to Host. Microbes and Infection, 11, 721-724. http://dx.doi.org/10.1016/j.micinf.2009.03.011

[29] Puerto, I.F., Zavala, J.E., Rosado-Franco, A. and Gamboa-Albornoz, L.J. (2004) Serological Survey of Borna Disease Virus in Schizophrenic Patients from Yucatan, Mexico. Revista Biomédica, 15, 141-147. 